\title{
Erratum to: Advances in systemic therapy for metastatic breast cancer: future perspectives
}

\author{
S. P. Corona ${ }^{1}$ - N. Sobhani ${ }^{2}$ - A. Ianza $^{2}$ - G. Roviello ${ }^{2}$ G. Mustacchi ${ }^{2}$. \\ M. Bortul ${ }^{2} \cdot$ F. Zanconati ${ }^{2} \cdot$ D. Generali ${ }^{2}$
}

Published online: 14 June 2017

(C) Springer Science+Business Media, LLC 2017

\section{Erratum to: Med Oncol (2017) 34:119 \\ DOI 10.1007/s12032-017-0975-5}

The original version of article unfortunately contained a mistake. The affiliation of the first author was incorrect, and this is now corrected through this erratum.

The online version of the original article can be found under doi:10.1007/s12032-017-0975-5.

D. Generali

dgenerali@units.it

1 Peter MacCallum Cancer Centre, Moorabbin Campus, 865 Centre Rd, Bentleigh East, VIC 3165, Australia

2 Department of Medical, Surgery and Health Sciences, University of Trieste, Piazza Ospitale 1, 34129 Trieste, Italy 